\title{
ON THE PROCEDURAL STATUS OF THE TRANSLATOR
}

Dyachenko A. F.

The article deals with various aspects of an interpreter's/translator's involvement in legal proceedings and provides different perspectives on the given problem. It demonstrates that the procedural status of an interpreter/translator may vary depending on the functions that he/she preforms, as well as the tasks to be solved. The legislator provides for the use of an interpreter's/translator's special knowledge only if in the criminal proceedings there is a need for interpreting/ translating explanations, testimony or documents, for this purpose the parties to the criminal process, the investigation judge or the court invite a relevant interpreter/translator. Though the real practical experience shows that his/her activity may be considerably wider: an interpreter/translator may be involved both as a specialist (e. g. identifying samples for an expert study) as well as an expert in conducting a comprehensive video-, audio-recording and linguistic examinations, or he/she can independently solve issue that arise within the forensic interpreting/translation examination. The article discusses the possibility of conducting identification and diagnostic studies of foreign speech or written text by an expert, whose knowledge of this language is not that of a native speaker, within comprehensive examinations with the use of an interpreter's/translator's special knowledge.

Keywords: translator, procedural status, specialist, expert, video-, audiorecording examination, linguistic examination, interpreting/translation examination.

УДК 343.98:331.45

B. T. Чупрун, старший науковий співробітник Харківського НДІСЕ

\section{ЩОДО ВВЕДЕННЯ НОВОГО ВИДУ СУДОВӦ̈ ЕКСПЕРТИЗИ - «ВІЙСЬКОВА»}

Визначено актуальність уведення нового виду судової експертизи - «військова». Показана необхідність розроблення ї̈ теоретичного й методологічного забезпечення. Розкрито зміст поняття «тактика» та наведено класифікацію воєнних дій, а також показано їх взаємозв'язок з оперативним мистеитвом і стратегією. Запропоновано орієнтовну класифікацію виду судової експертизи - «військова» на підвиди. Наведено вимоги до кваліфікайї й підготовки судового експерта за новою спеціальністю.

Ключові слова: судова військова експертиза, військове мистецтво, тактика, воєнні дії, збройний конфлікт, загальновійськовий бій, бойова підготовка, система управління військами.

Наказом Міністерства юстиції України від 27 лип. 2015 р. № 1350/5 унесені та затверджені зміни до Інструкції про призначення та проведення судових експертиз та експертних досліджень і Науково-методичних рекомен-

(C) Чупрун В. Т., 2015 
дацій з питань підготовки та призначення судових експертиз та експертних досліджень ${ }^{1}$. Серед інших змін найбільшої уваги, на розсуд автора, заслуговує доповнення Науково-методичних рекомендацій новим розділом IX «Військова експертиза». Інструкція, поряд з іншими нормативними документами, є керівництвом для судових експертних установ щодо організації їх діяльності. Але, на жаль, в Інструкції та в наявних на сьогодні нормативних документах, окрім основних завдань і орієнтовного переліку питань, що можуть вирішуватися при проведенні военної експертизи, інших даних не наведено.

Означене дає підстави вважати, що внесення до Науково-методичних рекомендацій такого виду судової експертизи, як «військова», по суті своїй $€$ декларативним. Безсумнівно, що цей вид експертизи (а точніше клас, якщо виходити із загальноприйнятої класифікації судових експертиз у експертологіï) на сьогодні є конче необхідним для слідчої й судової практики.

Реаліями сьогодення нашої держави є вдосконалення ефективної системи забезпечення національної безпеки та оборони. Аналізування збройного конфлікту в окремих районах Донецької й Луганської областей показав, що набуло тенденції, порівняно з минулим, розширення форм і способів його здійснення та збільшення чисельності залучених до нього сил. Конгломерат збройного конфлікту доповнився і його незмінним супутнім явищем - активізацією криміналітету. В умовах такого комплексного та широкого спектру впливу на національну безпеку України загалом особливого значення набуває завершення формування сектору безпеки й оборони та його подальший розвиток ${ }^{2}$.

Відомо, що зміцнення обороноздатності держави можливе лише за умови суттєвого поліпшення функціонування Збройних Сил (далі - 3С), інших військових формувань (далі - ВФ), правоохоронних, розвідувальних і контррозвідувальних органів, налагодження їх дієвої координації та взаємодії в процесі підготовки держави до оборони, а також під час надання відсічі збройній агресії або ліквідації збройного конфлікту. Україна має розраховувати виключно на боєздатність власних ЗС (інших ВФ).

У сучасних умовах і в майбутньому вирішальна роль у бою буде належати людині - воїну, що має високі моральні, бойові та психологічні якості, досконало володіє сучасною бойовою технікою й мистецтвом підготування та ведення бойових дій у складних умовах. При цьому постійно зростають вимоги до військовослужбовців і працівників ЗС (інших ВФ), що пов'язано з необхідністю забезпечення їх готовності до виконання бойових (службово-бойових) та інших завдань. Командування ЗС (інших

1 Див.: Про внесення змін до наказу Міністерства юстиції України від 08 жовтня 1998 року № 53/5 : наказ М-ва юстиції України від 27.07.2015 № 1350/5 // Офіц. вісн. України. - 2015. - № 58. - Ст. 1921.

2 Див.: Про внутрішнє та зовнішнє становище України у 2015 році : аналітична доповідь Національного інституту стратегічних досліджень до Щорічного Послання Президента України до Верховної Ради України [Електронний ресурс]. - Режим доступу : www.niss.gov.ua. http://www.niss.gov.ua/articles/1855/. 
ВФ), командири з'єднань, частин і підрозділів повинні постійно забезпечувати зміцнення військової дисципліни та правопорядку у військах.

Разом із тим слід відмітити, що в існуванні збройних сил, із часу їх зародження й нині, присутній такий негативний момент, як військові злочини. В історії не було таких ВФ, у яких би не траплялися ті чи інші злочини. Ця проблема не тільки ВФ України, військові злочини не мають кордонів, вони трапляються в арміях усіх країн світу. 3 ними ведеться непримиренна боротьба.

За свідченням давніх літописів в Україні в боротьбі з військовою злочинністю були задіяні певні посадові особи та сформовані спеціальні органи, які проводили нагляд за дотриманням установлених у військах обов'язків воїнами й виконанням ними наказів, внутрішнього розпорядку, збереженням довіреного майна та зброї. Так, дружинники княжого війська Київської Русі в разі вчинення злочину обов'язково несли покарання, при цьому це вирішувалося владою за участю самого князя. На Запорізькій Січі найвищою особою, яка у своїх діях втілювала боротьбу з правопорушенням у Війську Запорізькому, був кошовий отаман (гетьман), який уособлював у собі адміністративну, військову й духовну владу та наглядав за виконанням прийнятих рішень через козацьку старшину. Остання, у межах своєї компетенції та повноважень, проводила наглядові дії у визначених військових формуваннях, доводила справу до суду, який був гласний і швидкий. Смертю карали за зраду, ненадання допомоги товаришам у бою та ін. ${ }^{1}$

Притаманна така боротьба з проявами військової злочинності й у $3 \mathrm{C}$ (інших ВФ) нашої держави. За відповідними статтями Кримінального кодексу України військовими злочинами визнаються злочини проти встановленого законодавством порядку несення або проходження військової служби, учинені військовослужбовцями, а також військовозобов'язаними під час проходження ними навчальних (чи перевірних) або спеціальних зборів.

3 огляду на зазначене, слід констатувати наступне. Безпека у воєнній сфері розглядається сьогодні як одна з найважливіших складових національної безпеки нашої держави, яка передбачає створення необхідних умов для стійкого функціонування й розвитку ВФ, зниження ймовірності виникнення й обмеження масштабів негативних інцидентів, забезпечення соціальної стабільності. Проблема запобігання виникненню негативних інцидентів, пом'якшення їх наслідків вельми актуальна. Це зумовлено збільшенням людських і матеріальних втрат, які негативно впливають на функціонування ВФ. На сьогодні збитки від військових злочинів за своєю значимістю можливо зіставити з втратами в ході бойових дій.

Потреби слідчої й судової практики у вирішенні питань, які виникають при розслідуванні (судовому розгляді) справ стосовно виникнення негативних інцидентів при підготуванні та під час ведення дій (діяльності) 3С (інших ВФ) нашої держави, недотримання при цьому вимог нормативних актів із

1 Див.: Музиченко П. П. Історія держави та права України / П. П. Музиченко. К. : Знання, 2001. - С. 317. 
боку як керівного складу, так і підпорядкованих їм військовослужбовців, зумовлюють необхідність формування такого виду експертиз, як судова військова експертиза (далі - СВЕ).

Доречно відмітити, що свого часу в Харківському НДІСЕ на підставі напрацьованого досвіду акцентувалася увага «на необхідності для судового експерта додаткових спеціальних знань у воєнній сфері»" ${ }^{1}$ а також «на використанні вузько спрямованих спеціальних військових знань у відповідній галузі воєнної науки для науково обгрунтованого дослідження фактів, які мають доказове значення під час розслідування та розгляду справ у судах, пов'язаних із діяльністю ВФ»².

Аналізування розділу IX «Військова експертиза» Науково-методичних рекомендацій показав наступне. Згідно з означеним документом основними завданнями військової експертизи є встановлення:

- обставин застосування та дій військових формувань;

- обставин, що призвели до настання тяжких наслідків, загибелі людей (військовослужбовців, працівників Служби безпеки України, Збройних Сил України, Міністерства внутрішніх справ України, Національної гвардії України та інших представників міністерств і відомств, цивільного населення), втрати озброєння, військової техніки, об'єктів державної влади та інфраструктури, особистого майна громадян під час застосування військових формувань;

- відповідності дій (бездіяльності) посадових осіб вимогам керівних документів (покладених обов'язків).

На нашу думку, з таким формулюванням основних завдань військової експертизи в цілому можна погодитися, чого не можна сказати про перелік орієнтовних питань, що вирішуються. Швидше за все, наведений перелік орієнтовних питань більше притаманний певному типу судової експертизи, тому що він не охоплює всього спектра питань, які належать до предмета військового мистецтва та його складових частин. До наведеного висновку призводить аналіз змісту такої галузі воєнної науки, об'єктом дослідження (вивчення) якої є організоване застосування зброї й техніки в ході воєнних, антитерористичних і миротворчих дій, як воєнне мистецтво (далі- ВМ).

Предметом дослідження ВМ є операції, бої та інші форми воєнних, антитерористичних і миротворчих дій. Воєнне мистецтво поділяється на три складові елементи: стратегічне мистецтво; оперативне мистецтво; тактичне мистецтво. Такий розподіл породжений наявністю специфічних особливостей ведення воєнних дій різних рівнів, що дозволяє кожному складовому елементу конкретно та цілеспрямовано досліджувати організоване застосу-

1 Фокін Д. І. Актуальні питання судових експертних досліджень обставин нещасних випадків, пов'язаних із діяльністю у воєнній сфері / Д. І. Фокін, В. Т. Чупрун // Теорія та практика судової експертизи і криміналістики : зб. наук. праць. - X. : Право, 2013. - Вип. 13. - С. 360.

2 Чупрун В. Т. Щодо використання спеціальних знань при проведенні досліджень обставин нещасних випадків, пов'язаних із діяльністю у воєнній сфері / В. Т. Чупрун // Там само. — Х. : Право, 2014. — Вип. 14. - С. 306. 
вання зброї й техніки на тактичному, оперативному та стратегічному рівнях, яке належить до його предмета.

Воєнні дії - це організоване застосування зброї й техніки особовим складом законно створених військових формувань супротивних сторін у збройній боротьбі. Воєнні дії класифікуються:

— за видами - оборона й наступ;

- за рівнями - стратегічний, оперативний, тактичний. У ході ведення воєнних дій стратегічного та оперативного рівнів можуть виникати оперативно-стратегічний і оперативно-тактичний рівні відповідно. Рівень воєнних дій визначається значимістю завдань, які виконуються;

- за типами (воєнні дії на суші, на воді (морі) і в повітрі);

- за формами (бій, операція, битва, бойові дії та удар).

3 огляду на досвід застосування ЗС України (інших ВФ) у конфлікті в окремих районах Донецької й Луганської областей необхідно відмітити, що означені формування застосовували в більшості таку форму бойових дій, як бій. Військовим мистецтвом бій визначається як основна форма тактичних дій військ, що являє собою організовані й узгоджені за місцем, цілями та часом удари, вогонь і маневр з'єднань, частин та підрозділів з метою знищення (розгрому) противника, відбиття його ударів і виконання інших завдань в обмеженому районі протягом визначеного часу. Бій може бути загальновійськовим, протиповітряним, повітряним і морським ${ }^{1}$.

Визначальна роль в обороні держави належить Сухопутним військам 3С (далі - CВ). Сучасний бій СВ є загальновійським, оскільки ведеться об'єднаними зусиллями підрозділів, частин і з'єднань усіх родів військ із широким застосуванням танків, бронетранспортерів (бойових машин піхоти), артилерії, засобів протиповітряної оборони, літаків, вертольотів, а також іншої бойової техніки та озброєння і є об'єктом дослідження тактики² (тактичного мистецтва). Тактика охоплює вивчення, розроблення, підготування й ведення всіх видів бойових дій: оборони, наступу, зустрічного бою, перегрупувань тощо. Структурно тактика складається із: загальної тактики; тактики родів військ; тактики спеціальних військ; тактики з'єднань, частин і підрозділів інших військових формувань. Загальна тактика охоплює теорію та практику підготування й ведення загальновійськового бою з'єднаннями,

1 Див.: Тактика / под ред. В. Г. Резниченко. - 2-е изд., перераб. и доп. - М. : Воениздат, 1987. - 496 с.; Тактика (рота, батальон) / под ред. В. И. Крылова. - М. : Воениздат, 1991. - Ч. 2. - 497 с.; Мотострелковый (танковый) батальон в бою /под ред. Д. А. Драгунского. - М. : Воениздат, 1986. - 304 с.; Тактика загальновійськових підрозділів : навч. посібник / О. П. Романенко, В. І. Шарій, В. О. Варюхін та ін. К. : АЗСУ, 1998. - 494 с.

2 Тактика воєнна (грец. taktiká - мистецтво шикування військ, від tásso - будую війська) - складова частина військового мистецтва, що включає теорію й практику підготування та ведення бою з'єднаннями, частинами (кораблями) і підрозділами різних видів збройних сил, родів військ (сил) та спеціальних військ на суші, у повітрі й на морі (див.: Тактика: підручник / [В. В. Вішняков, Г. А. Дробаха, А. А. Каленський, Є. Б. Смірнов]. — К. : ВПЦ «Київ. ун-т», 2008. - С. 25). 
частинами та підрозділами. Тактика родів військ, спеціальних військ та інших військових формувань охоплює теорію й практику виконання завдань частинами та підрозділами родів військ, спеціальних військ та інших формувань.

Тактика, будучи окремим елементом військового мистецтва, тісно пов'язана з оперативним мистецтвом і стратегією. Взаємозв'язок складових елементів військового мистецтва потрібно розглядати через:

— бойові завдання - тактичні, оперативно-тактичні, оперативні, оперативно-стратегічні та стратегічні;

- військові формування, які ці завдання виконують: тактичні групи підрозділів, підрозділи, тактичні групи частин, частини, тактичні групи з'єднань, з'єднання, оперативно-тактичні об'єднання, оперативні об'єднання, оперативно-стратегічні об'єднання, стратегічні об'єднання;

- форми воєнних дій - бій, бойові дії, операції оперативного об’єднання, битва, операції стратегічних об'єднань;

- простір, у межах якого ведуться воєнні дії, наприклад для оборони (окоп, траншея, опорний пункт, район оборони, ділянка оборони частини, смуга оборони з'єднання, напрямок, операційний напрямок, стратегічний напрямок).

Треба підкреслити, що значний вплив на розвиток тактики має вдосконалення зброї та воєнної техніки. Озброєння й тактика завжди мають зворотний зв’язок. Зміни в одній категорії негайно приводять до змін в іншій, тому цей процес $є$ безперервним. Натепер підрозділи й частини армій більшості держав оснащені сучасним озброєнням і технікою, що дало змогу значною мірою підвищити їх ударні, вогневі й маневрові можливості, а також спричинило зміни в змісту самого бою. Бій став динамічним і швидкоплинним, таким, що вимагає від командирів усіх ступенів рішучості й активності, творчості й самостійності як під час організації бою, так і в ході його ведення.

Під впливом розвитку засобів збройної боротьби змінюються погляди на характер сучасного загальновійськового бою. Відомо, що немає нічого більш згубного в тактиці, як спроби вирішувати нові завдання старими методами. Глибоке осмислення умов бою, що змінюються, творчий розвиток тактичних положень і вміння командира застосовувати їх стали покликом часу. Якщо офіцер позбавлений гнучкості тактичного мислення, схильний до шаблону, то він у переважній більшості випадків не спроможний добитися успіху в бою1. В умовах усезростаючої динамічності бойових дій і нетиповості бойової обстановки від командирів і штабів вимагається оперативність і гнучкість керівництва (управління). 3 урахуванням наведеного надається можливим визначити, що особливу увагу треба приділяти вдосконаленню системи управління ЗС (іншими ВФ) на відповідних рівнях. У сучасних умовах вона має забезпечити, крім іншого,

1 Див.: Гридин В. О. Развитие тактического мышления у курсантов военных училищ / В. О. Гридин. - М. : Воениздат, 1991. — 256 с. 
ефективне керівництво міжвідомчими силами оборони під час відсічі збройної агресії противника.

Основою управління є рішення командира. Найбільш доцільне рішення, прийняте командиром (начальником) і доведене до військ, - запорука успішного виконання поставлених бойових (службово-бойових) завдань. Одним i3 найважливіших шляхів підвищення якості рішення $є$ його всебічне обгрунтування. Командир під час оцінювання обстановки та прийняття рішення повинен уміло опиратися на наукові методи, які передбачають використання об'єктивних кількісних і якісних показників, що характеризують умови обстановки, прогнозований результат запланованих бойових дій ${ }^{1}$.

Висока готовність до виконання бойових (службово-бойових) та інших завдань ЗС (іншими ВФ) безпосередньо пов'язана з удосконаленням систем їх оперативної та бойової підготовки, забезпеченням збільшення їх інтенсивності та масштабів. При цьому слід ураховувати особливості сучасної збройної боротьби. Так, Бойовим статутом Сухопутних військ, а саме частиною 2 (батальйон, рота), зазначено, що запорукою успіху в складних умовах сучасного загальновійськового бою є висока бойова виучка. Вона досягається в ході напруженої бойової підготовки, яка є основним змістом повсякденної діяльності військ у мирний час і продовжується при підготуванні до бою та в проміжках між бойовими діями. У ході бойової підготовки повинні враховуватися висока напруженість, швидкоплинність бойових дій та інші характерні риси сучасного загальновійськового бою. Підрозділи, які взаємодіють під час виконання бойових завдань, займаються бойовою підготовкою спільно. В умовах воєнного часу основна мета бойової підготовки - вивчити противника, який протистоїть, й оволодіти найбільш ефективними способами його розгрому в обстановці, що склалася² ${ }^{2}$ Тобто, бойова підготовка як вид підготовки Сухопутних військ ЗС України (інших ВФ) є основним змістом діяльності командирів, органів управління (штабів) і військ (сил).

Сучасний командир повинен органічно поєднувати в собі професіоналізм, глибоку компетентність, особисту дисциплінованість, ініціативу, творчий підхід до справи, зобов'язаний ефективно організовувати й планувати бойову підготовку. Науковцями Національного університету оборони України визначено поняття бойової підготовки як комплекс навчально-виховних заходів щодо навчання військовослужбовців і злагодження підрозділів, військових частин та з'єднань для виконання завдань згідно 3 призначенням, що проводиться з метою забезпечення постійної готовності підрозділів, частин і з’єднань до вирішення притаманних їм бойових завдань у складних умовах ведення сучасних бойових дій ${ }^{3}$. Планування

1 Див.: Вайнер В. Я. Тактические расчеты / В. Я. Вайнер. - 2-е изд., перераб. и доп. - М. : Воениздат, 1982. - 176 с.

2 Див.: Бойовий статут Сухопутних військ. Частина 2 (батальйон, рота). - К. : Варта, 1998. - С. 3.

3 Див.: Повсякденна діяльність військових частин. Ч. ІІ. Організація і методика бойової та мобілізаційної підготовки : підручник / [О. М. Ісаєв, В. І. Куренков, Л. В. Олійник та ін.]. — К. : НУОУ, 2011. — 344 с. 
заходів бойової підготовки здійснюється штабами на підставі знову ж таки рішення командира (начальника) на організацію бойової підготовки того чи іншого ВФ і під його безпосереднім керівництвом. Відповідно до рішення командира (начальника) у ВФ розробляються й основні плануючі документи.

3 огляду на зазначене автор на підставі особистого військового та експертного досвіду вважає за необхідне висловити своє бачення низки питань стосовно введення нового виду судової експертизи - «військова». Методологія судової експертизи в будь-якій сфері базується на загальній теорії судових експертиз (судовій експертології) ${ }^{1}$ і відображає основоположні наукові аспекти останньої на експертну діяльність у певних галузях. Новому виду судової експертизи, якщо він формується, треба визначити місце в класифікаційній експертній системі, для чого необхідно окреслити предмет, об'єкт, методи дослідження, коло спеціальних знань, якими повинен володіти експерт із даного напряму досліджень. Відзначені ознаки мають розглядатися в сукупності, тому що жодна 3 цих ознак, узята окремо, ізольовано, не дозволяє зрозуміти сутність певного виду судової експертизи, а також відмежувати один ії вид (підвид) від іншого.

У спеціальній літературі та в методології традиційних криміналістичних експертиз відсутнє поняття як об'єктів і методів проведення експертиз такого роду, так і самої їх сутності. Це може призвести в одних випадках до необгрунтованого розширення кола об'єктів та завдань, що вирішуються, а в других - суттєво звузити можливості застосування спеціальних знань при виконанні експертних досліджень цього виду. Тому, на нашу думку та 3 точки зору практичних вимог розслідування справ у зазначеній сфері, виникає необхідність визначення СВE, покликаної на підставі спеціальних військових знань експерта вирішувати експертні завдання стосовно дій (бездіяльності) військовослужбовців, що спрямовані проти встановленого законодавством порядку несення або проходження військової служби.

Уведенню нового виду судової експертизи однозначно повинно передувати розроблення теоретичних і методичних основ, визначення завдань та переліку вирішуваних питань, уточнення кола об’єктів. Чітке формулювання поняття «завдання судової експертизи», на думку автора, визначене Ю. К. Орловим. «Завдання експертизи - це ті питання, котрі повинні бути вирішені в ході іiі виконання. На перший погляд таке визначення не відрізняється від тлумачення предмета експертизи. У дійсності за обсягом вони можуть збігатися. Але разом із тим між ними існують суттєві відмінності, тому що вони відображають різні аспекти експертизи. Предмет - це те, що може бути встановлено експертизою, він визначає ііі можливості, не допускає виходу за ії межі. Завдання - це те, що повинно бути встановлено. Завдання не можуть виходити за межі предмета, але можуть бути більш вузькими. Завдання можуть бути вирішені повністю або частково, або не вирі-

1 Див.: Основы судебной экспертизы : в 2 ч. / под ред. Ю. Г. Корухова. - М. : РФЦСЭ, 1997. — Ч. 1. Общая теория. — 430 с. 
шені взагалі. Предмет від цього не змінюється, він залишається таким самим (безсумнівно, що з розвитком науки він також може зазнати змін, але це вже інший аспект)» ${ }^{1}$.

У юридичній літературі існує достатньо широкий діапазон суперечливих думок щодо класифікації криміналістичних експертних завдань, які змінюються в міру розвитку судової експертизи ${ }^{2}$. Слід підтримати думку М. Я. Сегая, що природа знань кожної науки визначається виключно її предметом як частиною об'єктивної дійсності, яку вивчає конкретна наука. Використання знань інших наук (фізики, хімії, біології, математики тощо) не змінює іiі предмета, ці знання лише пристосовуються для вирішення завдань, які на цю науку покладені ${ }^{3}$.

Комплекс завдань, які вирішуються із використанням спеціальних знань стосовно встановлення відповідності (невідповідності) підготовки та ведення дій (діяльності) вимогам (принципам) військового мистецтва, а також обставин, у яких вони здійснювалися та їх наслідків, надають можливість сформулювати поняття предмета СВЕ. Виходячи із трактування предмета експертизи в судовій експертології, можна визначити предмет СВЕ як фактичні дані (факти, обставини), що надані в матеріалах справи (провадження), які досліджуються та встановлюються на основі застосування спеціальних наукових і практичних знань у галузі військового мистецтва в межах вирішуваних завдань.

Різновидами об'єктів СВЕ можуть бути: текстові та графічні документи (стандартні на паперових носіях і електронні); відео- та аудіозаписи; фотознімки та інші носії інформації різноманітної природи.

Відповідно, виходячи з означеного, повинні бути визначені конкретні завдання, що вирішуються при проведенні СВЕ. Тільки після цього має бути сформульований орієнтовний перелік питань, які можуть виноситися на вирішення СBE.

На сьогодні склалася така ситуація: уведено новий вид судової експертизи - «військова» за відсутності розроблених їі теоретико-методологічних основ. При цьому слід зауважити, що до судових експертних установ такі експертизи вже надходять, тобто практичні потреби випередили теоретичні, а це, у свою чергу, виносить на перший план необхідність усунення означеного протиріччя.

1 Орлов Ю. К. Судебная экспертиза как средство доказывания в уголовном судопроизводстве / Ю. К. Орлов. - М. : Ин-т повышения квалификации РФЦСЭ, 2005. - C. 33 .

2 Див.: Корухов Ю. Г. Криминалистическая диагностика для экспертов : науч.практ. пособие. - М. : РФЦСЭ, 2007. — 225 с.; Основы судебной экспертизы : в 2 ч. / под ред. Ю. Г. Корухова; Энциклопедия судебной экспертизы / [Т. В. Аверьянова, Р. С. Белкин, Ю. Г. Корухов, Е. Р. Россинская]. - М. : Юристь, 1999. - 552 с.

3 Див.: Сегай М. Я. Судебная экспертология: объект, предмет, природа и система науки / М. Я. Сегай // Теорія та практика судової експертизи і криміналістики. - Х. : Право, 2003. - Вип. 3. - С. 25-27. 
Ураховуючи важливість і необхідність уведення такого виду судової експертизи, як «військова», та нагальну потребу в розробленні її теоретикометодологічного забезпечення, це завдання, на нашу думку, доцільно вирішувати на основі методу паралельної роботи, запозиченого із такої галузі воєнної науки, як «Військове управління». Її основами передбачено, що робота стосовно виконання рішення та самої його реалізації залежить від конкретної обстановки, отриманого завдання, наявності часу. Вона буває послідовною чи паралельною, можливе поєднання ${ }^{1}$. За умови наявності часу на роботу з підготування й виконання рішення застосовується метод послідовної роботи, за якого в нижчих інстанціях діяльність щодо ії виконання розпочинається після завершення означеного процесу у вищестоящій інстанції. За умови вкрай обмеженого часу застосовується, як правило, метод паралельної роботи. У такому разі реалізація рішення вищестоящої інстанції розпочинається в підпорядкованих їй структурах відразу ж після отримання певних вихідних даних. Одночасно з цим, вищестояща інстанція продовжує роботу з підготування й виконання рішення та координує її в підпорядкованих структурах.

У нашому випадку внесення до Науково-методичних рекомендацій такого виду судової експертизи, як «військова», мабуть необхідно вважати початковими даними. Означену роботу необхідно здійснювати також з урахуванням специфіки проблеми військових злочинів, яка, на думку автора, характеризується:

— відсутністю налагодженої дієвої системи профілактики та попередження військових злочинів;

- слабкими координацією дій і рівнем взаємодії органів, задіяних у боротьбі з військовою злочинністю;

- рівнем загальновійськової підготовки кадрів військових прокуратур.

Тому правомірними є запитання: Хто буде здійснювати розроблення положень CBE? Яким вимогам повинні відповідати судові експерти, що будуть залучатися до проведення СBE?

На підставі загальної теорії судової експертизи (судової експертології) надається можливим відмітити, що до спеціальних знань судового експерта, який залучатиметься до виконання СBE, належать знання законодавчих, основоположних нормативних актів (бойових статутів, настанов, керівництв тощо), що регламентують військову діяльність, тобто тих нормативних документів, які є основою для організації та практичної реалізації заходів як повсякденної, так і бойової діяльності ВФ. Це визначається насамперед тим, що для відповіді на поставлені питання експертизи недостатньо знайти потрібний нормативний акт і вивчити його, далі необхідно провести дослідження, засноване на спеціальних знаннях.

1 Див.: Стеценко О. О. Основи служби штабів / О. О. Стеценко, П. А. Савков, М. О. Ляхов ; за ред. О. О. Стеценка // Основи військового управління : навч. посібник. — К. : Ліра-К, 2007. — Ч. II. - 177 с. 
Процес управління військами, основу якого складає рішення відповідного командира (начальника), чітко регламентовано відповідними документами. Вирішення питань СВЕ не буде пов'язане тільки з вивченням та дослідженням документів. Дослідженню будуть підлягати також і практичні дії військовослужбовців у різних умовах обстановки, що не завжди, з урахуванням специфіки службової діяльності, може бути відображено (зафіксовано) документально. У цьому випадку визначну роль буде відігравати практичний військовий досвід експерта, оскільки доведеться також оцінювати (досліджувати) як несвоєчасне прийняття рішення та його реалізацію, так і їх відсутність.

Компетенцію будь-якого фахівця оцінюють за характером базової освіти. Означене свідчить про те, що судові експерти, які будуть залучатися до проведення СВЕ, повинні мати відповідну вищу воєнну освіту. При цьому слід звернути увагу на те, що повне й усебічне дослідження питань СВЕ тактичного рівня буде відповідати встановленим вимогам за умови розгляду їх із точки зору оперативно-тактичного рівня. Загальновідомо, що інформація стосовно діяльності будь-яких ВФ - це інформація з обмеженим доступом. Тому проблемним $є$ питання щодо допусків судових експертів, які будуть залучатися до проведення СВЕ, до такої інформації.

Як убачається із зазначеного, вимоги до судових експертів, які будуть залучатися до виконання СВE, достатньо специфічні. Така специфічність визначається насамперед положеннями ст. 3 Закону України «Про судову експертизу», згідно з якими судово-експертна діяльність здійснюється на принципах законності, незалежності, об'єктивності та повноти дослідження. Тобто, з одного боку, принцип повноти дослідження є основоположним, характеризує процес призначення та проведення експертизи, а 3 другого - неповнота дослідження завжди залишає сумніви в достовірності висновків ${ }^{1}$.

Підсумовуючи наведене, слід визначити таке. При виконанні певної CBE дослідженню повинні підлягати матеріалізовані об'єкти, у яких зафіксовані рішення відповідних командирів і методи роботи їх штабів при підготуванні й веденні бойових (службово-бойових) дій, а також у ході бойової підготовки. 3 урахуванням наявності специфічних особливостей ведення воєнних дій на тактичному, оперативному та стратегічному рівнях, убачається можливим розподілити СВЕ, як вид - на підвиди: СBЕ тактичного рівня і CBE оперативного рівня. Для виконання СBE необхідне введення відповідних експертних спеціальностей із розробленням належного методичного забезпечення.

За нашою думкою до виконання СВЕ доцільно залучати судових експертів, які повинні мати диплом вищого військового навчального закладу за

${ }^{1}$ Див. Захарченко О. В. Реалізація загальних умов судового розгляду при призначенні та проведенні експертизи / О. В. Захарченко // Актуальні питання судової експертизи та криміналістики : матеріали міжнарод. наук.-практ. конф., присвяч. 90-річчю створення Харківського НДІ судових експертиз ім. Засл. проф. М. С. Бокаріуса. - Х. : Право, 2013. - С. 81. 
командно-штабною, оперативно-тактичною спеціальністю певного роду військ, стаж практичної роботи в складі ВФ не менше 10 років.

Необхідність уперше висвітлити організаційні, методичні й правові основи судової військової експертизи зумовлюють певні труднощі, а тому в цьому матеріалі зроблено спробу почати розгляд актуальних питань СBE.

\section{О ВВЕДЕНИИ НОВОГО ВИДА СУДЕБНОЙ ЭКСПЕРТИЗЫ - «ВОЕННАЯ»}

Чупрун В. T.

Определена актуальность введения нового вида судебной экспертизы - «военная». Показана необходимость разработки ее теоретического и методологического обеспечения. Раскрыто содержание понятия «тактика» и приведена классификация военных действий, а также показана ее взаимосвязь с оперативным искусством и стратегией. Предложена ориентировочная классификачия вида судебной экспертизы - «военная» на подвиды. Приведены требования к квалификациии судебного эксперта по новой специальности.

Ключевые слова: судебная военная экспертиза, военное искусство, тактика, вооруженный конфликт, бой общевойсковой, боевая подготовка, система управления войсками.

\section{ON THE INTRODUCTION OF A NEW KIND OF A FORENSIC EXAMINATION - «WAR»}

\section{Chuprun V.T.}

The article determines the relevance of introducing a new type of a forensic examination - a «war» examination. It argues the necessity of its theoretical and methodological support. The article offers the subject and object of a forensic war examination and determines the array of its objects. It defines the notion of «tactics» and provides a classification of military actions as well as illustrates its interrelation with an operational planning skills and strategizing. By describing the components and the subject of the research in the field of war science, namely "the art of war», the author demonstrates the presence of particular features peculiar to military actions of different levels. This allows conducting a specific and targeted research by every component into the episodes of organized use of weapons and equipment at the tactical, operational and strategic levels. Based on these findings, the article suggests a tentative classification of forensic examinations - «war» and its subtypes with outlying the specific features of problems connected with war crimes. It also provides requirements to the qualifications and training of a forensic expert under this new specialization.

Keywords: forensic war examination, the art of war, tactics, armed conflict, combined arms operations, combat training, the system of commanding troops. 